European Journal of Probation

University of Bucharest

www.ejprob.ro

Vol. 1, No. 1, 2009, pp $41-65$

ISSN: 2066 - 2203

\title{
Surveillance and Confinement: Explaining and Understanding The Experience of Electronically Monitored Curfews ${ }^{1}$
}

\author{
Mike Nellis \\ Professor of Criminal and Community Justice \\ University of Strathclyde
}

\begin{abstract}
Electronic monitoring (EM) is now widely used in Western Europe, but its precise nature as a distinct form of penal sanction remains unclear. Since its advent in the USA in the 1980s, it has been most commonly characterized as a form of confinement and seen as an analogue of imprisonment. The names it had been given - "home detention", "community custody" and "curfew", for example - reflect this view. The surveillant aspects of EM have been vaguely acknowledged, but have relied on dubious ocular metaphors, and remain undertheorised. This paper will argue that EM should be understood primarily as a particular form and experience of surveillance, because the precise regulatory regime which it imposes on offenders (including the element of confinement) is only made possible by remote sensing technology, and has collateral effects alongside confinement. The paper concludes by tentatively placing this new, surveillant conceptualization of EM within contemporary debates on the changing nature of penalty.
\end{abstract}

\section{Key words:}

Electronic monitoring - Surveillance - Curfew - Offender perspective - Discipline

\section{Introduction}

Around the world, various forms of electronic monitoring (EM) technology are now used to supervise offenders, at the pre-trial (bail), community penalty and/or post-release supervision stages of the criminal justice process. The practice originated in the USA in 1982, spread to Canada and Australia, is now widely used in Western Europe, and is taking root in Eastern Europe (Toon and Nellis, 2008). Although voice verification, inmate tracing and satellite tracking EM-systems are in use in Europe, the commonest form of EM-technology is used to enforce curfews in the offender's own home (or other court-designated accommodation), for all or part of a day, sustained over a number of months (or more rarely, years). Worldwide, the Anglophone literature on EM-curfews overwhelmingly portrays them as an experience of confinement (or partial confinement) 
and the various names that have been given to them (especially in America) - "house arrest", "home incarceration", "home detention", "community custody" or "virtual prison" (Roberts, 2004) - even the term "curfew" itself -- bear witness to this understanding. Policymakers and academics alike have largely conceptualized EMcurfews as a way of "doing time at home" (Ball, Huff and Lilly, 1988) -- as the most selfevidently prison-like of all alternatives to prison -- and it is in these same terms (when research is undertaken) that offenders have been asked their perceptions of them.

This paper seeks to modify that conceptualization. It will argue that EM-curfews can and should also be understood as an experience of surveillance; indeed, that surveillance is the primary aspect of such measures, because the precise regulatory regime that is constituted in this penalty is only made possible by - is inconceivable without - remote monitoring technology. This point could perhaps be made more strongly in relation to satellite tracking (which monitors movement over a wide area, but usually includes a curfew as well), but the point I wish to emphasize is that even EM-curfews alone, which may seem to be best understood as confinement, have to be understood as surveillance first and foremost ${ }^{2}$. Allusions to the surveillant dimension of EM-curfews do exist in the literature - a minority of articles on EM even use "surveillance" in their titles -- but thus far the nature of the surveillance entailed has been seriously undertheorised, and it is that which this paper mostly seeks to rectify. It will do so by drawing particularly on EMresearch undertaken in England and Wales - where EM is routinely called "tagging" because a) there is a relatively large amount of it and b) the surveillant aspects of EMcurfews can be shown to be submerged within it, despite its predominant presentation of such curfews as "confinement". To give a preliminary example, which clearly implies that confinement-by-curfew may not be viable or meaningful without an underpinning surveillant apparatus: a bailed and tagged defendant once told Home Office researchers that "I've been on police curfew before [without EM], but it's better with the tag, as you know you've got to be there - without the tag, I didn't bother"' (Airs, Elliot and Conrad, 2000:44, emphasis added).

Full substantiation of the view that surveillance should be accorded greater prominence than confinement in studies of EM-curfews nonetheless requires more than a single suggestive quotation. It is essential, firstly, to understand the technology involved, and secondly, to accurately characterize EM as a distinct and particular socio-technical practice. Thus, the electronic monitoring of offenders in England and Wales mostly utilizes radio frequency (fro) communication and telephone technology (initially landline, increasingly mobile) to remotely check, in real time, on the physical presence or absence of a person in their own home (or other designated place such as a hostel). It is largely, but not exclusively used as a means of stimulating compliance with a nighttime curfew. Fro signals are transmitted from an ankle bracelet (or "tag" worn by the offender to a "home monitoring unit" (HMU) installed in his/her accommodation, and relayed to a distant monitoring centre staffed on a $24 / 7$ basis. Personnel there can be instantly alerted on screen if a person does not return home in time to begin a curfew, or if they leave home during a curfew, or if (while they are at home) they tamper with the tag or the HMU. They can also be in phone contact with the offender or his/her family. Understood thus, EM -- as a technology and an associated set of social practices -- is clearly a form 
of surveillance as David Lyon (2001:2) has defined it: "any collection and processing of personal data, whether identifiable or not, for the purposes of influencing or managing those whose data have been garnered".

Surveillance, however, (even of offenders) can take many socio-technical forms, of varying degrees of precision, depth and duration, which are manifestly not experienced in the same way as each other, so a more carefully honed definition of EM-assurveillance is still needed. Thus, within the broader field of offender supervision, EM can be described as a form of location monitoring which uses electronic sensors to secure compliance with a specified routine of temporal and spatial regulations sustained over a set period of time -- in this instance, the curfew and its associated rules. As a sentence of the court, or as a measure of penal administration, an EM-curfew places a degree of trust in the offender and requires their active participation (e.g. to be home at a specified time, to take care of the equipment), as well as seeking in some degree (over and above mere obedience to the schedules) to prompt responsible, law-abiding behavior at least for the duration of the order.

It is, however, a moot point how comprehensively the offender's mind (thinking) is being targeted by EM. Attentiveness towards rules is required of the offender, but compared to the aspirations of specific attitude and behavior change programmes relatively little by way of cognitive change is (or can) be expected of it. Far from the offender's mind being targeted, it is more obviously the presence or absence of the offender's tagged body from specific premises at specific times - registered remotely as a trace on a computer screen -- on which preliminary judgments are made as to whether or not compliance has occurred. These judgments are then verified by telephone calls and/or visits to the home and, singly or cumulatively, form the basis on which subsequent decisions to take breach action (return to court or prison) are made. EM-curfews can operate as a stand-alone measure or as a component of a multi-modal sentence with a range of other elements -attitude and behavior change programmes, counseling or therapy, drug treatment and testing, or education. As a form of surveillance-based compliance checking, it can thus be operated separately from, or in conjunction with the more conventional incentive-based, trust-based and threat-based forms of securing compliance associated with the community supervision of offenders (Nellis, 2004). Threat-based forms - grounded in a concept of deterrence - are particularly important, as failure to comply with an EMcurfew is likely to lead (in principle and in the mind of the tagged offender) to a more onerous penal sanction.

As a penal strategy, EM-curfews have been controversial (more so in some countries than others), with different stakeholders in their development projecting a range of meanings onto them, each implicitly -- and sometimes explicitly -- imagining "what it would be like" for an offender to experience it. Tom Stacey (1989), who originally envisioned it in England and Wales (and coined the term "tagging"), believed that "the wearing of a... tag means living with an imminent tap-on-the-shoulder" which, he claimed many offenders would welcome as an alternative to the destructive environment of prison. The Home Office believed that it would be a tough, high tariff "punishment in the community", more onerous than probation -- and also more efficient, because (other 
things being equal) offenders would quickly calculate that the tag vastly increased the likelihood of detention if violations of curfews occurred (Nellis, 1991). The English Probation Service itself initially rejected EM as anathema to the caring ethos of their work with "clients", fearing that the technology would be intrusive and unreliable, and that curfews would create unbearable tensions within the home (Kay and Pratt, 1993). Later, some in the Service accepted that EM could be sensibly incorporated within its humanistic traditions and even suggested that the technology's very impersonality might be a virtue -- enabling those offenders who have psychological difficulty accepting personal authority to be more compliant than they might be with a human supervisor (Whitfield, 1997; 2001).

\section{Evaluating Electronic Monitoring - Incorporating Offender Perspectives}

The reliance in this paper on evaluations of various EM-curfew pilot schemes undertaken in England and Wales does risk making its arguments and conclusions nationally and culturally specific, because different cultures and traditions, and different political configurations, do indeed respond to penal innovation and change in different ways. I would argue, however, that while there are demonstrably cross-national differences in the way EM has been implemented, and may well be in the way offenders experience EM (as yet imperfectly understood) the basic analytical distinction I wish to make between "surveillance" and "confinement" would be useful to researchers in any European country.

The first English pilot, for adults on bail, ran for six months in 1989/1990 (Mair and Nee, 1990), and the second, with sentenced adult offenders in the mid-nineties (Mair and Mortimer, 1996; Mortimer and May, 1997). This then segued into a national roll-out of EM in 1999 as both a sentence and as a form of early release from prison. Juveniles between the ages of 10 and 17 became eligible for tagging, and EM bail was reintroduced, in 2000 (Elliot, Airs, Easton and Lewis, 2000; Airs, Elliot and Conrad, 2000). These studies mostly focused on offender's compliance with the EM-curfew requirement, but some also contained data on offenders' and their families' perceptions of the experience, usually using very small samples (20 or less). Given that over 400,000 offenders have been tagged since 1999, and that on any one day in England and Wales there are 17,500 tagged individuals in the community, surprisingly few have been asked about their experience of it.

In England and Wales, the law permits sentenced individuals to be tagged for up to 12 hours per day for a maximum period of six months. The offender's consent is not required. The hours per day during which one can be curfewed are greater on bail and parole, which arguably place greater burdens on their families. The maximum period that one can be released early from prison on the tag rose from 60 through 90 to the present 135 days. Very few people have been tagged and curfewed for any length of time episodes are measured in weeks and months. The majority have been in their twenties and thirties. All studies of EM-curfews indicate they have progressively been used on a wide range of offences: the recent joint inspectorate examination of 286 curfew cases, drawn from across England and Wales broke down as follows: 33\% offences of violence, 11\% 
motoring offences, $11 \%$ burglary, $8 \%$ theft, $7 \%$ robbery, $6 \%$ criminal damage and $23 \%$ other (including "failing to send a child to school") (Her Majesty's Inspectorates of Probation, Court Administration and Constabulary 2008, para 4.9)

Official evaluations have largely been concerned with issues relevant to "performance management" and "service improvement". Information has been sought for quality assurance purposes, and to inform operational and strategic decisions, hence the focus on compliance rates, levels of restrictiveness, the views of family members on whom the tagged offender's presence impacts, and on the quality of offender and family relationships with the private sector monitoring company staff who install, explain and check the equipment that makes remote monitoring possible. Only certain dimensions of the offender's experience (gathered in single interview situations) are considered officially relevant, and their recorded answers have tended to reflect the questions they were asked. Comments are usually aggregated and reported as decontextualised soundbites, rather than as sustained, reflective narratives, which has the effect of dissipating individual, biographical experience. Knight, Kemshall and Dominey (2007) have recently delivered a withering critique of such "satisfaction survey" approaches to gathering offender perceptions (even as a "performance management tool), and outlined a research strategy for gaining a more in-depth understanding of offenders' subjective experience.

In short, the narrowness and shallowness of official evaluations of EM, in respect of offender perceptions, means that we cannot claim to know much about the latter's subjective experience of it. Little has actually been asked about surveillance, little vouchsafed - although hints have been given. It is possible that the surveillant dimensions of EM are neither clear nor prominent in many offenders' minds, but we cannot be certain of this until we make suitable, sensitive enquires. It is, however, in the nature of some forms of surveillance for subjects to be unaware (or not fully aware) of it, or to lack an adequate vocabulary for articulating their subjectivity, and indeed for surveilling authorities to represent their practices in language that does not foreground ideas about surveillance.

Can the official evaluations be improved upon? The National Audit Office's (2006) costeffectiveness study of EM-curfews was methodologically similar to the earlier evaluations, asking only 18 offenders (from urban, suburban and rural areas) for their experiences. Home Office evaluations have, however, been supplemented by a number of personal accounts either by independent researchers (Richardson, 1997, 2002) or probation officials (Shaw, 1997) who were testing the equipment, and by offenders themselves (Taylor, 2000, Aitken, 2005); There have been student dissertations (Pepper, 2000 , Felton, 2003) ${ }^{3}$, comment by press and TV journalists, and one independent study, which asked 76 EM-curfewed offenders about their experiences (Hucklesby, 2008). Apart from the latter, these supplements are not without their own methodological limitations, but have usually asked somewhat broader and deeper questions than the official evaluations. Of them, only Richardson provides a narrative account of her experience of EM which overtly -- although not unproblematically -- places the sense of being surveilled at its heart. 
It should be recognized that some of the available data on offenders' experiences of EMcurfews in England and Wales is now almost twenty years old. Offenders in 2008 have become more "knowledgeable subjects" in respect of EM-curfews than the first bailed defendants in 1989 could possibly have been (Mair and Nee, 1990). They are able, for example, to compare experiences of tagging with friends and associates in a given locality, pick up on hostile media coverage, and have possibly experienced EM in more than one context, say, first as an element in a community sentence, later as part of postprison supervision. They may have learned first hand some of the human/social limitations of the monitoring system, and/or how to spoof and resist the technology. EMcurfew technology itself has changed, generally having become easier to interact with (although satellite tracking technology is more complex). HMUs are no longer the size of a fax machine and no longer require the tag to be placed in direct contact with them in order to "verify presence" (see Richardson, 2002: 40/1 for the bodily contortions involved). Moreover, monitoring company staff in both field and centre have accumulated considerable experience since the early days of EM and -- notwithstanding larger workloads -- their interaction with tagged offenders and their families is likely to be far more informed than it was ( see Paterson, 2007).

\section{American Research on Offender Perspectives}

The most theoretically sophisticated work on offender experiences of EM to date comes from two researchers in the USA, Brian Payne and Randy Gainey, although typically for American work on this particular "intermediate sanction", they emphasize "house arrest" (confinement) and attend only obliquely to EM (surveillance). In 1998, they imaginatively compared "the pains of imprisonment" as conceptualized by Gresham Sykes (1958) with the "pains of EM-house arrest" via an analysis of questionnaires administered to 29 offenders. Sykes listed the pains of imprisonment as deprivation of autonomy -- a vast body of rules and commands that take away personal control; deprivation of goods and services -- loss of opportunity to earn money and buy what one wants; deprivation of liberty -- restriction on movement, separation from key people, loss of some civil rights; deprivation of heterosexual relations -- separation from sexual partners; deprivation of security -- living at the mercy of predatory prisoners (and maybe prison staff). Elements of these deprivations also applied to EM-house arrest, but in the main its pains were rather different: monetary costs -- having to pay $\$ 70$ per week for the equipment ${ }^{4}$; family effects -- the inconveniencing of family members -- and potential increases in domestic tension; watching others effects -- seeing others, particularly friends and family, do things that you can't do; experiencing temptation; bracelet effects -- the discomfort of the tag, the effect on choice of clothing, the stigma and shame of people seeing it. Payne and Gainey (1998) concluded that while most offenders found EM-house arrest to be onerous, they still preferred it to imprisonment.

In a later work Payne and Gainey (2004) further explored the perceptions of 49 people who experienced EM after release from prison. They were mostly men, just under half of whom were white, spanning ages 21 to 63 for drink driving offences and a range of felonies and misdemeanors. In essence Payne and Gainey explored their experience of 
EM along four interrelated dimensions -- the kind of daily living problems it posed for them, whether and how it deterred them from further crime, whether it restricted their freedom and how it compared with being in jail. Interestingly, as in the earlier study they do not use the word "surveillance" and the one thing that is truly distinctive about EMcurfews as a community penalty -- the capacity of a supervisor to know in real-time whether one is at home or not -- is subsumed under the findings on deterrence, the fear of being given a worse penalty if one does not comply. This can of course apply to breach of any community penalty, but it is clear from Payne and Gainey's research that it is precisely "the monitoring potential of the electronic technology" that helps to make the prospect of painful consequences more vivid:

One offender commented that escape was not an option "because this [the bracelet] has a range and they will know pretty quick" In a similar vein, another offender indicated, "Wherever you go they are ahead of you". And another said, "They'd know if the bracelet were off". More specific in terms of the monitor's strength, a fourth offender commented, "I don't see it as easy to escape. My monitor picks me up within five feet of the door. I'm out at 7.30am in the morning and in at 7.30 at night. If I'm late she knows" (Payne and Gainey, 2004:425).

Payne and Gainey concede that this is not the only reason why offenders comply with their curfews -- the latter appreciate the ties to their families (whilst sometimes finding sustained proximity difficult), they take time to reflect on their behavior -- but is it still the presence of surveillance technology in their lives (in their homes) which shapes and conditions all their other interactions -- their domestic relations, the sense of freedom, their precise losses as a result of home confinement and their gratitude at being out of jail. Other, more humanistic, community penalties such as probation and community service, for example, may entail temporal and spatial demands (keeping appointments, punctual attendance at work-sites), induce reflectiveness and elicit fear of worse consequences if rules are not upheld -- but they do not do so by placing monitoring technology on an offender's body and in their homes and requiring them to remain there for set periods. As a strategy for securing and checking compliance, EM is different in kind from other community penalties -- and it can either be used separately or in conjunction with them. Nothing that Payne and Gainey say contradicts this but despite having produced the best available work on offender perspectives regarding EM, they seemingly do not recognize that it is more of a surveillant than a custodial form of control.

\section{The Surveillant Dimensions of Electronic Monitoring}

Using offender and researcher comment this section seeks to reframe EM-curfews as an experience of surveillance as well as an experience of confinement, indeed to show that such curfews are only accepted and experienced as confinement because the offender has to make a reflexive response to a monitoring technology which can record and transmit basic data on his/her presence in or absence from specific premises. Pace Roberts (2004) EM-curfews are only "community custody" or "virtual prisons" in metaphoric senses of 
these penal terms ${ }^{5}$. They are more literally -- and more accurately -- characterized as partial restrictions on movement rather than compared, analogically, to fixed places of sequestration. They routinely leave the tagged offender with a constant (possibly agonizing) choice about remaining in a specified place -- a choice that the locks, bolts, and bars of a closed prison emphatically take away. Socially and psychologically, EMcurfews are a different sort of experience to imprisonment or incapacitation -- one is not separated from one's family, one may continue going to work -- and they entail a range of experiences derived from the presence of monitoring technology in offender's lives -the potential visibility of the tag in public space -- rather than the requirement to remain indoors. As described here - and drawing on Ball (2008) - the surveillant dimensions of EM-curfews (in relation both to curfew orders (a community penalty) and home detention curfews (post-prison monitoring) have elements of both exposure (revelation of information) and intrusion (specific prohibitions and behavioral requirements). I will take examples of surveillance from the existing English evaluations of EM-curfews, characterizing, for convenience, the 1989-90 research as the "first phase", the 1996-2000 research as "second phase" and the 2006-2007 research as the "third phase".

\section{The Human Aspect of Monitoring}

EM is not simply a technology, and entails a considerable amount of personal contact both with field monitoring officers (who install the HMUs and fit tags) and the monitoring centre staff (who phone to check upon absences and are contacted when technical problems arise). This, together with the operation of the technology itself, can make for high levels of intrusiveness and disruption of daily (or nightly) life. Half the first phase respondents were annoyed by this (Mair and Nee, 1990). In the second phase tags were not always fitted properly, HMUs beeped unnecessarily, some tags falsely emitted "battery low" signs to the monitoring company, and the phone occasionally rang in the middle of the night (Mair and Mortimer 1996: 24). Even in the third phase "it was quite rare for a box [HMU] not to have been replaced in its time: in one instance, Premier ended up supplying seven different boxes due to faults" (NAO, 2006: 46). Sometimes maintenance visits take place inconveniently late at night -- say $11 \mathrm{pm} \mathrm{--} \mathrm{but} \mathrm{as}$ monitoring officers can only visit a home during curfew hours (usually after $7 \mathrm{pm}$ ), have unpredictably busy nights depending on how many orders come in from court in the later afternoon and may have to travel long distances, this is sometimes unavoidable. Some of the visits are made necessary because offenders test boundaries, both social and spatial, in the early stages of an EM-curfew.

Field monitoring officers shape offenders' and families' initial expectations of the EMcurfew experience. They explain the rules of the curfew, how the equipment works, what to do and what not to do, how to contact the monitoring centre, and supply further written information. This framing function may have been more important in the past than it is now (particularly for people who have experienced tagging more than once) but it is still something monitoring officers are required to do, and how well they do it may have a bearing on how well prepared families are for the onerousness of enforced proximity. Whilst monitoring officers' contacts are intrinsically intrusive, the official evaluations indicate that they are generally perceived by offenders as courteous, administratively 
helpful (if somewhat pedantic), and supportive in crises (see Taylor (2000) for a more critical account). Richardson also appreciated the personal touch and believed that their firm but friendly advice would have a salutary effect on offenders:

I found it reassuring to hear a human voice amid invisible and impersonal surveillance. To be told that I was the loser if I did not comply made me think of the consequences and my personal responsibility. ... I was tightly and efficiently controlled, there were no two ways about it. Having tried, I knew I could not defeat the system... No lies, no excuses for absences were accepted. "They" seemed to know all, being recorded on their computers" (2002: 41).

\section{Marking The Body}

The continuous remote monitoring of an offender's location is only possible, at present levels of technological development, if the offender wears a visible signaling device, usually strapped on their ankle (wrist tags only being allowed for pregnant women). The body is not modified (as it is with an implanted radio-frequency identification [RFID] chip), but it is marked (tagged) in order to make it surveillable. In the context of community supervision, and indeed of contemporary surveillance, this form of intrusion is one of EM's more unique features. The early tags were uncomfortable to wear, and some offenders asked for it to be swapped from leg to leg on a week by week basis to make it more comfortable (Mair and Nee, 1990: 59). Nowadays, only a few respondents say that it is 'a bit uncomfortable', especially in warm weather. Doubtless to make a virtue of its technical necessity, EM's champions have sometimes suggested that the continual presence of the tag on the ankle serves as a constant material reminder of one's surveilled status, and as an incentive to law-abidingness, and perhaps for some it does. Nonetheless, evidence suggests that the tag soon ceases to be physically noticeable: "after a while you don't know you have got it on" (Mair and Mortimer, 1996:22); "I very quickly became accustomed to wearing it, and after a couple of days I was almost unaware of it, (except when running when the rubbing on my ankle was quite painful" (Richardson, 2002:41); "the ankle bracelet was quickly adapted to and within a week was hardly noticeable" (Shaw (1997: 161) Richardson and Shaw both agreed from experience that, in bed, the hard plastic tag could painfully bump one's sleeping partner, while Mair and Nee (1990:59) found a respondent who claimed the tag was intrusive during sexual activities and upset his girlfriend. Sartorial considerations mean that wearing the tag does cause more problems for women offenders: as Richardson (2002) put it "the tag made a normally simple task like wearing tights difficult (the whole pair had to be thread through the small space between ankle and tag). Boots were almost impossible to wear, being too narrow to accommodate a tagged ankle". The NAO (2006: 46) quoted women who, whilst they were glad not to be in prison, "mentioned that the actual tag was not very feminine and was quite difficult to hide, leading to embarrassment for themselves and their family in public areas such as school or swimming bath". Echoing comments from earlier phases, all third phase respondents were agreed that tags "should be made more visibly pleasing and less obvious" (idem). 


\section{The Potential for Stigma}

Following on from the above, given that a wearable tag is necessary to make location monitoring possible, surveillance in this instance exposes individual offenders to the risk of stigma (and to unwarranted assumptions on the part of the public as to the type of offender they might be, which does raise issues of informational privacy). No other community penalty in England (apart from the "yellow bibs" worm by offenders doing "community payback" [erstwhile community service] since November 2008) has quite the potential to reveal to others that a person is an offender: as Goffman (1965) would put it, it "spoils" the identity they might otherwise project, whether in public or more intimate situations. First phase respondents clearly experienced this stigma. "Over half of those spoken to felt embarrassed about wearing the bracelet and did their best to cover it up in public (usually using a sock or a bandage)" (Mair and Nee, 1990: 58). Respondents generally minded less if family and friends saw it than if strangers saw it. Eight respondents claimed indifference as to whether anyone saw the tag, but others took steps to cover it up, for example:

It depends who it is who sees it. Like if I was sitting on the bus and someone saw it, that would worry me, but, like friends and relatives, it doesn't. When I sit down, I push my trousers down like that, so no one sees it (idem).

The increasing miniaturization of the electronic components inside tags has made possible ever more discreet ankle bracelets; unlike some American states, where unnecessarily large tags are still used precisely because they are visibly stigmatizing, the Home Office has always wanted tags to be unobtrusive, and the manufacturers have obliged. For men, at least, tags are easily concealed in public. For women it has always been more difficult, and for both a tag cannot easily be disguised when playing sports or going swimming. In the second phase, Shaw (1997:161) noted of the public that "it was rare for anyone apparently to notice it and even rarer for them to comment. Of the few who did, most thought it was a pedometer or some sort of security device. It was neither a problem nor an embarrassment". Richardson (2002: 41) had a similar experience: "On my last 'tagging' day I went to town by bus wearing a skirt to expose the tag. Although visible, it raised no eyebrows". She had been more wary of this in the early stages, because "a local newspaper had reported a violent incident involving a tagged mistakenly identified as a pedophile". This incident was not unique. In instances where local or national media coverage has indicated that sex offenders were being tagged, climates were seemingly created in which any person seen wearing a tag might be thought to be a sex offender, and shunned or assaulted accordingly. The possibility of being misrecognised as a sex offender may deter other offenders from consenting to the tag, or make them wary of traveling far from home.

Within the home, the HMUs could be a source of embarrassment. Placed next to the phone, their bulk and color made them conspicuous. Pepper (2000) found respondents who placed a doily over the box so that people could not tell what it was. It is not only 
offenders who experience stigma -- there is stigma-by-association for family members. Mair and Mortimer (1996: 24) noted "one mother of an offender [who] said that only close family friends knew about their son's order and that as a result they had not invited his grandparents to visit while the order was continuing". There was no mention of stigma or shame in the NAO report, but that does not, of course, mean it was not experienced. Some press reports have suggested that for some younger offenders, being tagged may well signify status rather than stigma, but hard evidence here is thin.

One particular aspect of stigma relates -- somewhat paradoxically -- to employability. Supporters of EM have long maintained that the ability to hold a job whilst tagged was one of the attractions of EM over prison. This may be true for offenders who are already in work, but the NAO (2006: 45) echoed Mair and Nee's (1990:58) comments from sixteen years previously in respect of offenders seeking work, who all believed that "employers would be less likely to offer them a job if they found out they were tagged". Although courts have proved willing to vary curfew hours in order to suit offender's working hours, some offenders will refuse requests for overtime or shift work rather than declare they are tagged (Dodgson et al., 2001) .

\section{The Question of Privacy}

The earliest commentators on EM-curfews recognized that they were in some obvious sense an "invasion of privacy" (Ball and Lilly, 1988), but the precise way in which one is exposed whilst tagged still needs unpacking. Privacy -- commonly (if somewhat unemotionally) defined as the control of information about ourselves -- has several dimensions, and EM-curfews do not impinge equally on all of them. Such curfews are not an ocular, aural or mobile form of surveillance -- the offender is not watched, overheard or tracked. But they do specifically focus upon an offender's home, their "domestic sphere". The assumed inviolability of the home from unwanted intrusion has traditionally been a very salient aspect of personal privacy. As geographer Peter Saunders once put it, for adults home is where they can,

be themselves, establish their own rules of conduct and feel relatively secure. The home is where people are off-stage, free from surveillance, in control of their immediate environment. It is their castle. It is where they feel they belong (Saunders, 1989:184 emphasis added).

The precise, concrete meaning of "home" to a particular cluster of people, in a particular time and place, is in fact an empirical question, and it may well register differently for children and young people, and for women in oppressive relationships with men (Aungle, 1994). Rossler's (2005) distinction between informational privacy and locational privacy is helpful here. EM-curfews clearly impinge on the latter, in the sense of letting distant supervisors know whether one is at home or not at certain set times, but have less bearing on the former. In reality, the precise way in which EM-curfews impact on privacy is a mix of the two: what they yield to the monitoring centre is information (in the form of an on-screen signifier) on a person's whereabouts over a specified period. They can 
expose where an offender is (or is not, when he should be), but because they do not make homes transparent they cannot expose what he or she is doing; a great deal of the offender's privacy is, ostensibly, left intact. The locational and informational privacy of other householders is not violated at all -- they can in theory come and go as they please -- although family members may in practice feel obliged to stay indoors with the offender, rather than go out without him (or her).

Experience in this area may, however, be more complex than is implied above: people's emotional experience of privacy may not be as segmented as the analytic distinction between its locational and informational aspects implies. When Richardson began to test the speed of the contractor's response to her deliberate violations (leaving home before her curfew ended, or returning five minutes late) she became preoccupied with it. The phoned responses -- picked up by her husband -- were rapid, coming within minutes of her absence being noted electronically. "I was amazed at the speed of the checking", she said. "It was as if the contractors were watching and knew exactly my whereabouts -quite an unnerving experience. I was usually asked [on the phone] where I had been, being reminded I was in breach of my court order, and given another official warning" (Richardson, 2002:40). Mair and Mortimer (1996:24) had casually mentioned "the feeling that you were being watched" as one of the disadvantages of being tagged, without apparently exploring in depth exactly what respondents meant by this. Richardson, on the other hand, suggests that a felt loss of locational privacy can segue into something more comprehensively unsettling, eventually articulating her experience of EM in terms of vivid ocular metaphors and the presumed exercise of "panoptic power",

\begin{abstract}
Although I knew nothing about my invisible 'controllers', they appeared to know an awful lot about me (did I imagine it?) I felt their invisible presence right into my home, almost like ghosts, observing and reporting on me. It was if I had lost the privacy of my thoughts, as if they could see through me too. It was as though my invisible self was becoming visible to outsiders. I felt transparent, naked. Not knowing for certain what they knew or did not know was pretty unsettling...

It was like being behind a one-way mirror; my movements were recorded by them, but I could not see what they had recorded of my life. I had to admit they were right about my absences. ... I was forced to accept their superiority, and therefore, whether I liked it or not, made to comply or face the consequences of my breaches... My life was in my own hands. I had to be responsible for myself (Richardson, 2002: 41).
\end{abstract}

Although it was not known to Securicor's monitoring staff (only to the local manager), Richardson was a researcher not an offender, and was only able to articulate her experience in these terms because of the "socio-literary" knowledge she already possessed. Skeptics might characterize her account as a discursive embellishment of what, at the time, was perhaps a rather more inchoate and ambiguous feeling. EM is a sensor 
technology which (when used with curfews) exposes presence or absence, but it is emphatically not a technology of visual or mental surveillance -- it cannot see into people's houses, still less into their minds (although it may have reflexive cognitive effects). Nonetheless, because we know so little about the phenomenology of surveillance, the way experiences of it are configured in consciousness, the skeptic's position can quite reasonably be inverted. Richardson's style of expression may reflect the educated vocabulary that was available to her, but her deeper intimations of "being watched" -the uneasy "sense of being stared at" identified by scientist Rupert Sheldrake (2003) -may in fact be more commonplace among those on EM-curfews. No one has ever sought to find out. It may well be that the sense of being known remotely in one way -being cognizant of geographically distant technicians who can pinpoint one's location -inexorably induces apprehensions that one might be "exposed to view" in other ways, producing the kind of abjection that Richardson mimics.

\section{The Degree of Restrictiveness}

The ostensibly punitive element of an EM-curfew is the curfew rather than the tag itself (which is indeed why, in official discourse, "confinement" is seen as its most salient characteristic). Formally if not substantively, an EM-curfew turns the home into penal space, and requires an offender to reside there for so many hours per day, for so many weeks and months. In doing so, it deprives an offender of access to outside social contacts and leisure activities. It does so not in the incapacitate manner of imprisonment or a ball and chain; there are no physical means of preventing an offender from disregarding or even removing the tag. EM-penalties prohibit but do not physically inhibit -- the restraint they impose is a calculated self-restraint. They invite the offender to forego desirable outside activities as a matter of his/her own volition, knowing that a) any violation of the curfew will be quickly discovered (because of the monitoring technology), and b) that any subsequent punishment is likely to be more onerous. As Payne and Gainey noted in their comments on temptation, knowing that one could so easily do something -- but deliberately refraining -- can be more painful than knowing, whilst locked in one's prison cell, that one simply doesn't have the option.

The first phase respondents found EM-bail more like a remand in custody than bail with "ordinary" conditions. There was an overwhelming feeling of restriction of liberty -"much more so than the respondents had expected" (Mair and Nee, 1990: 55). Eight offenders, six of whom had curfews of between 19 and 22 hours -- likened monitoring "to being a prisoner in their own home" (idem: 56). They experienced boredom, frustration and temptation. Even these defendants preferred EM-curfews to prison, because they enjoyed home comforts and being with family and friends, especially children. The second phase respondents -- sentenced offenders whose curfews did not exceed 12 hours per day -- preferred tagging to custody, nine of them having experienced both. It enabled them to retain employment, or to continue work on personal difficulties whilst on probation. Some believed tagging was an easier option than other community penalties (it merely required obedience), some the opposite (probation permitted more freedom). Six respondents were simultaneously on probation/ (Mair and Mortimer, 1996) 
A marked preference for EM over prison holds good in the third phase of research, in which respondents were asked to compare the experience of EM with other non-custodial penalties:

There was widespread agreement that electronic monitoring was a more effective punitive measure than fines. If people could afford the fine, it was not seen as an effective punishment, and where people could not pay the fine, it was likely that their family would suffer the financial consequences. Electronic monitoring was generally viewed as more effective than community service. However, a few respondents felt that it should still be combined with community service as they felt that curfewees were not learning the humbling lessons that community service teaches. (NAO, 2006: 44)

The duration of an EM-curfew affects one's capacity to undergo it: the longer one is curfewed the less bearable it is. Eleven of the first phase respondents "felt that the situation on monitoring became harder to bear as time went on, and said that they felt more and more temptation to abscond" (Mair and Nee, 1990: 59) -- seven of these either had been, or were subsequently re-arrested. Of defendants who perceived EM bail in less onerous terms, "who felt that temptation remained constant or actually diminished as time passed, only four were re-arrested" (idem). Second phase respondents had similar views: "At first I thought it was cushy but later I found that it was more of a drag... you have to work with it" (Mair and Mortimer, 1996:22).

\section{The Impact on Families and Partners}

All community punishments potentially impinge on the family of an offender in some degree, but with EM-curfews "collateral Intrusion" is greater: the householder's consent is required before an offender can be tagged to reside there. Mair and Nee (1990: 24) noted that "family members tended to be supportive, recognizing the curfew kept their son out of trouble. Some wives felt the inconvenience of it, but put up with it for the sake of the offender, and in the hope that something good would come of it". Family support seems crucial to successful compliance with an EM curfew (Mair and Mortimer 1996). While the younger offenders (who lived with parents) often felt positive about being on EM, the parents sometimes experienced it as a burden, feeling responsible for ensuring their child's compliance with their order. Realizing that EM impacted on their families sometimes had a salutary effect on curfewees - "they felt guilty because they were imposing a form of curfew on their partners who generally stayed in the house with them" (NAO, 2006:45)

Release after prison on HDC may be more domestically stressful than receiving a curfew order. The NAO notes one curfewee saying of his relationship that "prison was tearing us apart", but gives more emphasis to the likelihood of "strain... due to the sudden impact of spending a lot of time with someone after time apart". They quote a young male adult offender: 
We've spent 13 and a half months apart and now we've been forced into a house for twelve hours, forced back together or such a long time... it's still taking us time to adjust back to each other (NAO, 2006: 45).

There is no exact way to grade the "penal severity" of an EM-curfew -- the quality of the experience depends significantly on the size of a home, the facilities available and the demeanour of the people with whom one shares it (Felton 2003). Jonathan Aitken, a former MP, served his 60 days on HDC in his luxurious London town house, in which he "calculated that as a tagged prisoner [he] could now move around in a space almost a thousand times larger than the dimensions of a prison cell. This felt like real freedom even if I was a curfewee" (Aitken, 2005:178). Most offenders do not experience HDC in such lavish surroundings, and in smaller houses and tower block tiny flats may well resemble cells. There are also serious issues about managing children within the electronic envelope, which can restrict curfewees going into their back gardens or the street in front of their home:

parents reported difficulties in keeping order over their children as they could not leave the house to collect/discipline them. In addition to this, some parents felt that the safety of their children was jeopardized because they felt uncertain dealing with emergency situations due to the restrictions, therefore putting their child in danger NAO: 2002:45)

\section{Behavioral Responses}

Precise behavioral responses to any surveillance technology should be investigated rather than assumed; there may be dissonance between intentions and expectations on the one hand, and actual behavior on the other. Straightforward compliance is problematic (Hucklesby, 2009). In principle, EM-technology increases the risk of violations (relating to designated times and places) being detected, which in turn enhances the risk of a more severe sanction being imposed if non-compliance is proved. In the former respect at least "surveillance-based compliance" notionally makes a distinct contribution to deterrence, in the latter it is no different to other community penalties, where "threat-based compliance" has long existed as a means of inducing compliance. But what forms of behavioral response - instead of, or over and above compliance - do EM-curfews actually induce? Whilst not conceived by government, in any strong sense, as a means of changing longer term attitudes and behavior - they were initially envisaged either as a temporary constraint on offending or as a merely retributive, liberty-restricting punishment - EM curfews, alone or in association with other factors, may well contribute

to "thinking twice" and desisting from crime, as all sanctions at least have the potential to do:

Being tagged made me realize I had more to lose than I thought. It gives you time to reflect. 
I've pulled my socks up since I've been on it. I've got a job. (Mair and Mortimer, 1996: 23)

Approximately half the sample in Hucklesby's (2008) research ( $\mathrm{n}=76$ overall) claimed that the curfew helped them to stop or reduce offending, the other half reported no change. Some simply changed their patterns of offending to daytime, others didn't, fearing the increased risks of being caught. Some feared greater punishment if they disregarded the curfew. One third anticipated continuing with lifestyles that included offending. Having to be home in time for a curfew meant some did not stay out drinking as they might otherwise have done. Hucklesby concludes that EM-curfews had the potential to create windows of opportunity, to break habits - associations with "situations, people, places and networks that are correlated with their offending" (Hucklesby, 2008:66) - and possibly to expose offenders to the beneficial influence of law-abiding members of their families - although this was by no means widespread. She nonetheless underplays the crucial significance of surveillance technology. It was only when offenders took the curfew seriously that they complied with it, and their fear of consequences was vivid and realistic precisely because of the ease and frequency with which non-compliance could be ascertained. Although she improves on previous British researcher's work in significant ways, she too, like Payne and Gainey, fails to fully conceptualize the surveillant dimensions of the EM experience.

Whilst EM-technology in itself permits the transmission of data on presence or absence in real-time, the essentially bureaucratic processes of judging whether a violation has occurred, of initiating breach action in order to enforce compliance can be complex and time-consuming. This means that, for the offender, there may be no immediate consequence for a failure to comply with curfew times, which may weaken the deterrent effect of being surveilled, and induce further risk taking. A recent joint report by several criminal justice inspectorates concluded that, in England, poor communication between the private companies and the statutory agencies played a significant part in causing misjudgments and/or delays in breach action, while admitting that the governmentwritten protocols which framed this communication were themselves unduly complex and easily misunderstood. The situation was further complicated by differences in decision-making structures and in enforcement practice between court-ordered EMcurfews and the Home Detention Curfews following release from prison. In the case of the former they concluded that the exercise of discretion (by monitoring companies or offender managers in statutory agencies) was somewhat lax, and that the actual breach rate was still too high (a third of all orders) given the relative shortness of EM-curfews (six month maxima) compared to other community penalties. In the case of Home Detention Curfew they found instances "of overly assiduous enforcement, where it benefited no-one to return the offender to prison" (Her Majesty's Inspectorates of Probation, Court Administration and Constabulary, 2008: para 1.25). These examples serve vividly to remind us that EM is indeed a socio-technical practice whose administrative forms and precise impact on offenders is indelibly shaped by "human agency" (Paterson, 2007) and not just by technology - the location data it generates always requires a personal response. 
This complicates the issue of whether or not real-time remote location monitoring actually functions, routinely, as a deterrent; perhaps the best that can be said is that it has a unique potential to do so. Compliance rates (for other than minor technical violations) generally remain high, especially on post-release schemes, but instances exist where offenders have signally failed to be deterred, have cut off their tags and committed serious crimes before, finally, being apprehended (see, for example, the case of Peter Williams (Her Majesty's Inspectorate of Probation 2007; Nellis, 2006). Nonetheless, in the absence of evidence to the contrary many tagged offenders in the first instance probably do assume that "surveillance works", and that if they wish to evade its controls they will have to actively seek to do so, rather than taking advantage of haphazard enforcement by the authorities, which they may also learn to do. Compared, say, to CCTV (McGrail, 2002: Gill and Loveday, 2003), very little is known about the ways offenders find of thwarting and resisting EM-technology. There is much rumor and innuendo, and strong criticisms have periodically been made in the press and on television regarding resistance to tagging, based on interviews with young men who claim to have either ignored restrictions or cut off the tag with impunity. The NAO (2006: 46) respondents claimed to know of ways of tampering with the tag, but (perhaps for obvious reasons) did not report trying any of them and claimed to be skeptical of their efficacy. Encasing a tag in tinfoil is generally rumored to block the signal, but what would be of most use to an offender would be a way of getting the tag to continue emitting signals after it has been removed, leaving it at home and then going out. It is not the case that "being in the bath" (except wrought iron ones) blocks the signal from the tag to the HMU, although this excuse is frequently offered to explain an apparent absence from home.

Other forms of resistance and subversion are possible. A tagged offender may not be exposed to the "contamination affect" of prison culture, but can still mix with other criminals in his neighborhood in his "free time", or even invite them round to his house (to deal drugs, perhaps?) while under curfew. Hucklesby (2008) reports a mixed picture in respect of illegal substance misuse - some using less under curfew, some using more. Some offenders drank less outside the home as a result of the curfew - they could not linger in the pub - but some drank more at home. Some offenders simply mount legal challenges to EM, mostly in respect of alleged malfunctions by the technology, although a young woman has successfully challenged wearing the tag on sartorial grounds.

\section{Conclusion}

Since their introduction in England in 1989, and especially since their national roll-out a decade later, EM-curfews have created an expanding cohort of offenders who have experienced penal intervention in wholly new ways, a new category of surveilled subjects. This paper has adumbrated key dimensions of that experience, by elucidating both the precise (non-ocular) nature of the surveillance technology involved, and by using offenders' own comments to identify its experiential consequences. In essence, it has regulatory effects above and beyond mere confinement, and is not sensed, subjectively, to be confinement alone. This conclusion now seeks to locate this better conceptualized understanding of EM in broader debates about the changing nature of late modern 
penalty. Although placing spatial and temporal restrictions on offenders can be (and is) undertaken in the community without tagging, efficient and meaningful enforcement (particularly where large numbers are involved) would be prohibitively difficult without remote monitoring technology. From two monitoring centres, in the cities of Manchester and Norwich respectively, teams of monitors check the locations of 17,500 offenders per day in England and Wales. On each monitor's screen scores of geographically dispersed, digital presences can simultaneously be displayed. Each curfewed body is a node in a vast information/telecommunications network, which (to a limited degree) renders them "telepresent" to the monitors. Small numbers of monitors can thus confirm or deny the agreed whereabouts of thousands of tagged offenders, unseen by the offenders themselves - although they may occasionally be in telephone contact with them.

Metaphorically -- and metaphorically only - one can characterize this as "panopticism", "superpanopticism" (Poster 1995), or even, to use Paul Virilio's (1994) term, the expression of a "vision machine", but the trouble with all ocular metaphors is that they misrepresent the kind of exposure which EM-curfews entail ${ }^{6}$. EM makes known a physical location, it does not see a body or a person -- although whether an offender subjectively experiences tagging as being seen/watched is, as noted earlier, a matter warranting further investigation. The tagged individual is exposed to authority as a realtime digital presence, for part of a day, over a number of weeks or months. Understood in this way, it becomes difficult to portray EM as a disciplinary penalty in the traditional Foucauldian sense. It does not in itself require the internalization of norms from a tutelary authority like a probation officer. It does not intrinsically require the changes to attitudes and behavior which probation seeks to elicit - all that is required for compliance to be acknowledged in respect of EM is strict adherence to a predetermined temporal and spatial schedule. What matters is bodily presence in a specific location and sticking to a rule which enables that: "being there" or "not being there".

Nor - despite their being temporary prohibitions on movement - do EM-curfews create wholly "docile bodies" in the Foucauldian sense. The effort and organization required to keep to curfew times, plus constant worries about the consequences of minor violations, can cause anxiety and stress both for the offender and those with whom $\mathrm{s} / \mathrm{he}$ lives. Notwithstanding that time spent indoors can well be experienced as boredom, offenders subject to EM-curfews, part of whose lives are still lived outside the home, have to be "actively obedient" rather than "docile". EM-curfews arguably exemplify what Adam Crawford (2003) has called the "contractual governance" of individuals - coercive invitations to "regulated self-regulation", to abide by - to obey - a rule laid down by authority, Unlike the "anti-social behavior contracts" examined by Crawford (which do have disciplinary elements), the only behavior formally required by EM is compliance with the curfew times. That, and being available and responsive to monitoring officers, is all that an offender needs to be attentive to and reflective about. For the duration of the curfew one orientates one's life around the demands of a surveillance technology (to stay indoors) rather than a norm of law-abidingness.

Except for the element of personal volition that always remains with EM, it thus resembles Deleuzean (1992) "control" more than Foucauldian "discipline": indeed 
Deleuze himself (though he had tracking in mind) used the example of an "electronic collar" which enables the monitoring of movement to signify the transition from the fading "societies of discipline" to the emerging "societies of control". The former require internally transformed and reconstituted subjects, the latter merely require subjects who continually obey externally imposed rules (whether they are internally transformed or not). In the late modern world, the community supervision of offenders need no longer rely solely on what had once been its mainstay -- the periodic physical copresence of offender and supervisor. Henceforth, telepresence might sometimes be enough, or at least a useful additional element in a supervision programme (Nellis, 2009). Contemporary computerized control technologies can structure and modulate a person's mobility in space and time by micro-managing external environmental pressures -openings here, barriers there, inclusion now, exclusion later -- rather than seeking to change their personality (alter their way of thinking). Changing thought -- the traditional intention of discipline -- becomes less vital if the state can regulate sufficiently well in other ways -- co-opting and customizing the emergent telecommunications infrastructure to enable remote location monitoring serves to make elements of what Garland (1985) called the "penal-welfare complex" if not redundant, then at least less important. Furthermore, while EM-technology does individuate -- pick up the digital trace of a single body as it arrives home -- it does not (cannot) individualize, in the sense of generating knowledge of a person's distinct and idiosyncratic characteristics, as a probation officer might once have done. The mark on the screen in the monitoring centre which indicates that the tagged body is present in a house is a depersonalized entity, an atomized signifier -- and that is all that is needed for an authority to judge whether or not compliance has occurred.

In operational practice, of course, the discipline/control dichotomy is not so stark, and in the "automated socio-technical system" (Lianos and Douglas, 2000) which EM-penalties instantiate, several models of regulation operate simultaneously. The total experience of EM-curfews entails both electronic exposure and physical intrusion - monitoring officers visit one's home to fit the tag on one's body and install and periodically check surveillance equipment. While there is no intrinsic normative requirement to become lawabiding whilst tagged -- there is merely an instrumental spatio-temporal constraint upon lawbreaking -- courts who use this sanction may well expect offenders to "change their ways", just as they might if an offender had been punished with a fine. Her Majesty's Inspectorates of Probation, Court Administration and Constabulary (2008) in fact give several recent examples of courts deliberately timing EM-curfews to disrupt offending patterns, which may become more common if EM-curfews become more integrated into broader supervision strategies. Insofar as EM-curfews can be experienced as habitbreaking, as Hucklesby (2008) has shown they can, this is not an unreasonable expectation. Ad hoc disciplinary influences, alongside any sentencer's expectations, may be brought to bear on the monitored individual via family, friends and colleagues, by monitoring officers and even by probation officers (if they are involved), who each capitalize in their own way on the opportunity for change that is potentially afforded by the EM-curfew. It needs finally to be emphasized, however, that any "disciplinary effect" of an EM-curfew is incidental to the technology and the penalty, rather than being integral to it, whatever sentencers may intend or expect. For some sentencers, in any case, 
the imposition of an EM-curfew is no more than a retributive or deterrent punishment, a time-limited restriction of liberty, which is all, at root, that the technology permits.

That said, I am not arguing here that there is an "effect of EM-technology "unmediated by the welter of social influences and expectations to which a tagged individual is subject. I am arguing that the use of sensor technology/remote location monitoring as a form of offender supervision creates a new modality of penal experience, different in kind from all previous forms. In it, "the controlled" must necessarily orient themselves towards the impersonal signaling capacities of electronic devices in order to demonstrate compliance, and to avert more onerous punishment. Their experience is primarily one of surveillance (low exposure/medium intrusion), and only secondarily of confinement, even if they are unable, themselves, to articulate this with any degree of conceptual or verbal sophistication. Whereas custody (high exposure/high intrusion) entails removing a person to a place of confinement in order to discipline them, using on-site resources, EM-curfews entail the use of surveillance technology to enforce the partial sequestration of a person (usually) in a domestic space, whose impact is not inherently disciplinary (though sometimes it may in practice be so). By dint of the tag on the ankle EM -- the bodily marker which makes surveillance possible -- curfews also have collateral consequences outside the home (a sense of stigma or status, the adoption of concealment strategies, and restrictions on participation in night-time public life) which become inseparable from the overall punitive experience. Recognizing that EM-curfews are essentially a form of surveillant practice which enables finely calibrated forms of spatial and temporal regulation to be constituted as a penal sanction, rather than seeing them as a mere analogue of imprisonment, should -- among other things -- enable us to frame better questions for those subject to it than we have asked hitherto.

\section{Endnotes}

1. The original version of this paper was presented at an ESRC seminar on "The Everyday Life of Surveillance" at the University of Sheffield on 30th April 2008 and benefitted from comments made there. I am also grateful to Bob Lilly, of Northern Kentucky University; Kirstie Ball of the Surveillance Studies Network, Barry Snelgrove of the Ministry of Justice Electronic Monitoring Team and to two anonymous reviewers for further clarifying my thinking about the issues in question.

2. Offenders may well experience satellite tracking - which can be used either to monitor their movements in general as well as the perimeter of zones from which they are excluded - differently from the way they experience EM-curfews. The English satellite tracking pilots in 2004-2006 were suggestive in this respect, but not conclusive (see Shute, 2007; Nellis, 2008; see also Elzinga and Nijboer, 2006)

3. These student dissertations were completed by trainee probation officers undertaking the BA Community Justice at the University of Birmingham. 
4. Monetary costs do not apply in England and Wales, or in Western Europe. The equipment is loaned to the offenders.

5. It is because the term "prison" has such extensive metaphoric uses in everyday English vocabulary that we have so easily fallen prey to seeing EM-curfews as confinement rather than surveillance. We refer, for example, to (bad) "marriages as prison" to convey a sense of the way one or both partners experience restriction, although empirically a marriage does not resemble a prison at all. Faced with something new in the 1980s and 1900s -electronic monitoring -- penal analysts fell back on the most easily available way of making it intelligible -- likening it to imprisonment. EM had sufficient prison-like characteristics to make this plausible, but other not so prison-like features were obscured by this metaphor. It is true that from the outset EM has periodically been described as "Big Brother" -- a ready-to-hand surveillance metaphor -- but as surveillance metaphors go this is in itself pretty limiting.

6. The vernacular vocabularies that we routinely use to describe the now very variegated forms of surveillance are saturated with ocular metaphors (e.g. seeing, transparency, opacity, visibility). Our analytical vocabularies have not yet gone sufficiently far beyond them -- indeed cannot go far beyond them if they are to remain intelligible in public discourse. Even Virilio (1994), with his terms "vision machine" and "opto-electronics", uses ocular metaphors to characterize remote monitoring devices which are as likely to detect presence, gather digital data and register sound as they are to "see" appearances. Conceptualization in this area is further complicated by the fact that "seeing" can itself be a metaphor for "knowing" or "understanding", as in "I see what you mean". Bentham's original panopticon and (in a different way) modern CCTV systems are quite literally "vision machines", but Poster's "superpanopticon" (premised on databases) is not in essence a means of visualization -- it can make something knowable ("visible" in a metaphoric sense) but it cannot literally see. Sensor technology is a more neutral term than "vision machine", and any precise conceptualization of a subject's experience of surveillance must delineate exactly which particular facets of being are actually exposed by what types of sensor technology, as well as the (perhaps unsophisticated) vocabularies which subjects use to account for them.

Email: mike.nellis@strath.ac.uk 


\section{References}

Airs J, Elliot R and Conrad E (2000) Electronically Monitored Curfew as a Condition of Bail - report of a pilot. London: Home Office

Aitken J (2005) Porridge and Passion. London: Continuum

Aungle A (1994) The Prison and the Home: a study of the relationship between domesticity and penalty. Sydney: Sydney University Law School Institute of Criminology

Ball K (2008) Exposure: exploring the subject of surveillance. Paper circulated at ESRC seminar 'The Everyday Life of Surveillance'. Sheffield, 30th March 2008

Ball R A, Huff R J and Lilly JR (1988) House Arrest and Correctional Policy: doing time at home. Newbury Park, California: Sage

Ball R A and Lilly J R (1988) 'Home Incarceration with Electronic Monitoring' in Scott J E and Hirschi T (eds.) Controversial Issues in Crime and Justice. London: Sage

Crawford A (2003) "Contractual Governance" of Deviant Behavior. Journal of Law and Society 30(4) 479-505

Deleuze G (1992) Postscript on the Societies of Control. October 59. 3-7

Dodgson K, Goodwin P, Howard, Llewellyn-Thomas, Mortimer E, Russell N and Weiner M (2001) Electronic Monitoring of Released Prisoners: an evaluation of the Home detention curfew scheme. Home Office Research Study 222. London: Home Office

Elliot R, Airs J, Easton C and Lewis R (2000) Electronically Monitored Curfew for 1516 year olds - report of the pilot. Home Office Occasional Paper. London: Home Office

Felton S (2003) Home Detention Curfew: equal punishment for all? Dissertation for BA Community Justice University of Birmingham

Gainey R R and Payne B K (2000) Understanding the Experience of House Arrest with Electronic Monitoring: an analysis of quantitative and qualitative data. International Journal of Offender Therapy and Comparative Criminology. 44(1) 84-96

Garland D (1985) Punishment and Welfare: a history of penal strategies . Aldershot: Gower. 
Gill M and Loveday K (2003) What Do Offenders Think About CCTV ? in Gill M (ed) $C C T V$. Leicester: Perpetuity Press

Goffman E (1965) Stigma: Notes on the Management of Spoiled Identity. Harmondsworth: Penguin.

Her Majesty's Inspectorate of Probation (2007) Inquiry into the Supervision of Peter Williams by Nottingham City Youth Offending Team. London: Her Majesty's Inspectorate of Probation

Her Majesty's Inspectorates of Probation, Court Administration and Constabulary (2008) A Complicated Business: a joint inspection of electronically monitored curfew requirements order and licences. London: Ministry of Justice.

Hucklesby A (2008) Vehicles of Desistance? The Impact of Electronically Monitored Curfews. Criminology and Criminal Justice 8 51-57

Hucklesby A (2009) Understanding Compliance: a case study of electronic monitoring. Journal of Law and Society (forthcoming)

Kay J and Pratt D (1993) in Lilly J R and Himan J (eds.) The Electronic Monitoring of Offenders. De Montfort University Law Monographs. Leicester: de Montfort.

Knight V, Kemshall H and Dominey J (2007) Gathering Offender Perceptions of Probation Programmes : potential, pitfalls and limits. British Journal of Community Justice 5(1) 65-78

Lianos M and Douglas M (2000) Dangerisation and the End of Deviance: the institutional environment in Garland D and Sparks R (eds.) Criminology and Social Theory. Oxford: Clarendon Press

Lilly J R and Ball R (1987) A Brief History of House Arrest and Electronic Monitoring. Northern Kentucky Law Review 13. 343-74

Lyon D (2001) Surveillance Society: monitoring everyday life. Milton Keynes: Open University Press

Mair G and Nee C (1990) Electronic Monitoring: the trials and their results. Home Office Research Study 120. London: Home Office

Mair G and Mortimer E (1996) Curfew Orders with Electronic Monitoring. Home Office Research Study 163. London Home Office.

McGrail B A (2002) Confronting Electronic Surveillance: desiring and resisting new technologies. in Woolgar S (ed) Virtual society? ; technology, cyberbole, reality. Oxford: Oxford University Press 
Mortimer and May (1997) Electronic Monitoring in Practice: the second year of the trials of curfew orders. Home office Research Study 177: London: Home Office

Nellis M (1991) The Electronic Monitoring of Offenders in England and Wales; recent developments and future prospects. British Journal of Criminology 31(2) 165185

Nellis M (2004) Electronic Monitoring and the Community Supervision of Offenders. in Bottoms, A E, Rex S and Gelsthorpe L (eds). Cullompton: Willan.

Nellis M (2006) The Limitations of Electronic Monitoring: the tagging of Peter Williams. Prison Service Journal issue 164 March 2006 3-12

Nellis M (2008) 24/7/369: Mobility, Locatability and the Satellite Tracking of Offenders. in Aas K F, Gundhus H O and Lomell H M (eds.) Technologies of Insecurity: the surveillance of everyday life. London: Routledge

Nellis M (2009) Electronic Monitoring and Penal Control in a Telematic Society. in Doaks J, Knepper P and Shapland J (eds.) Urban Crime Prevention, Surveillance and Restorative Justice: issues in social technology. FL. Boca Raton: Taylor and Francis (CRC Press)

Paterson C (2007) "Street Level Surveillance" : Human Agency and The Electronic Monitoring of Offenders . Surveillance and Society 4(4) 314-328

Payne B K and Gainey R R (1998) A Qualitative Assessment of the Pains Experienced on Electronic Monitoring. International Journal of Offender Therapy and Comparative Criminology. 42(2) 149-163

Payne B K and Gainey R R (2004) The Electronic Monitoring of Offenders released from Jail or Prison: safety, control and comparisons to the incarceration experience. The Prison Journal 84(4) 413-435

Pepper L (2000) Home Detention Curfew: the offender perspective. Dissertation for BA Community Justice University of Birmingham

Poster M (1995) The Second Media Age . Cambridge: Polity Press

Richardson F (2002) A Personal Experience of Tagging. Prison Service Journal Issue 142. 39-42

Richardson F (1999) Electronic Tagging of Offenders: trials in England. Howard Journal: 38(2) 158-172 
Roberts J (2004) The Virtual Prison: community custody and the evolution of imprisonment. Cambridge: Cambridge University Press

Rossler B (2005) The Value of Privacy. Cambridge: Polity Press

Saunders P (1989) The Meaning of "Home" in Contemporary Culture. Housing studies 4(3) 177-192)

Shaw R (1997) Electronic Monitoring: what are the real issues? Justice of the Peace June 28th 1997

Sheldrake R (2003) The Sense of Being Stared At. London: Arrow

Shute S (2007) The Satellite Tracking Pilots in England and Wales: Research Summary. London. Ministry of Justice

Stacey T (1989) Why Tagging will Encourage Self Discipline for Offenders. Letters, Social Work Today 29th June 1989. 11

Taylor S (2000) Chain Reaction. The Guardian 12th January 2000

Toon J and Nellis M (2008) Electronic Monitoring. Report of the $5^{\text {th }}$ Conference on Electronic Monitoring at Egmond aan Zee 10-12 $2^{\text {th }}$ May 2007. Utrecht: Conference Permanente Europenne de la Probation (CEP)

Virilio P (1994) The Vision Machine: London: British Film Institute.

Whitfield D (2001) The Magic Bracelet. Winchester: Waterside Press.

Whitfield D (1997) Tackling the Tag. Winchester: Waterside Press. 